\title{
The Use of Stable Sulfur, Oxygen and Hydrogen Isotope Ratios as Geochemical Tracers of Sulfates in the Podwiśniówka Acid Drainage Area (South-Central Poland)
}

\author{
Zdzisław M. Migaszewski • Agnieszka Gałuszka • Artur Michalik • \\ Sabina Dołęgowska • Andrzej Migaszewski $\cdot$ Stanisław Hałas • \\ Andrzej Trembaczowski
}

Received: 4 December 2012/ Accepted: 16 April 2013/Published online: 26 April 2013

(C) The Author(s) 2013. This article is published with open access at Springerlink.com

\begin{abstract}
The paper presents the results of determinations of stable S and O isotopes of dissolved sulfates and $\mathrm{O}$ and $\mathrm{H}$ stable isotopes of waters from three ponds, that is, Marczakowe Doły acid pond, Marczakowe Doły fish pond and Podwiśniówka acid pit pond, located in the Holy Cross Mountains (south-central Poland). The $\delta^{34} \mathrm{~S}_{\mathrm{V}-\mathrm{CDT}}$ and $\delta^{18} \mathrm{O}_{\mathrm{V} \text {-SMOW }}$ of $\mathrm{SO}_{4}{ }^{2-}$ in waters of three ponds $(n=14)$ varied from -16.2 to $-9.5 \%$ (mean of $-13.6 \%$ ) and from -8.1 to $-3.2 \%$ (mean of $-4.8 \%$ ), respectively. The mean $\delta^{34} \mathrm{~S}-\mathrm{SO}_{4}{ }^{2-}$ values were closer to those of pyrite (mean of $-25.4 \%$ ) and efflorescent sulfate salts (mean of $-25.6 \%$ ), recorded previously in the Podwiśniówka quarry, than to sulfates derived from other anthropogenic or soil and bedrock sources. The $\mathrm{SO}_{4}{ }^{2-}$ ions formed by bacterially induced pyrite oxidation combined with bacterial (dissimilatory) dissolved sulfate reduction, and presumably with subordinate mineralization of carbonbonded sulfur compounds, especially in both Marczakowe Doły ponds. In addition, the comparison of $\delta^{18} \mathrm{O}-\mathrm{SO}_{4}{ }^{2-}$ and $\delta^{18} \mathrm{O}-\mathrm{H}_{2} \mathrm{O}$ values indicated that $75-100 \%$ of sulfate oxygen was derived from water. Due to the largest size, the Podwiśniówka acid pit pond revealed distinct seasonal variations in both $\delta^{18} \mathrm{O}-\mathrm{H}_{2} \mathrm{O}(-9.2$ to -1.6$)$ and $\delta \mathrm{D}-\mathrm{H}_{2} \mathrm{O}$ $(-29.7$ to -71.3$)$ values. The strong correlation coefficient $\left(r^{2}=0.99\right)$ was noted between $\delta^{18} \mathrm{O}-\mathrm{H}_{2} \mathrm{O}$ and $\delta \mathrm{D}-\mathrm{H}_{2} \mathrm{O}$ values, which points to atmospheric precipitation as the only source of water. The sediments of both acid ponds display different mineral inventory: the Marczakowe Doły acid pond sediment consists of schwertmannite and goethite, whereas Podwiśniówka acid pit pond sediment is composed of quartz, illite, chlorite and kaolinite with some admixture of jarosite reflecting a more acidic environment. Geochemical modeling of two acid ponds indicated that the saturation indices of schwertmannite and nanosized $\varepsilon-\mathrm{Fe}_{2} \mathrm{O}_{3}\left(\mathrm{Fe}^{3+}\right.$ oxide polymorph) were closest to thermodynamic equilibrium
\end{abstract}

Z. M. Migaszewski $(\bowtie) \cdot$ A. Gałuszka · A. Michalik $\cdot$ S. Dołęgowska

Jan Kochanowski University, 15G Świętokrzyska St., 25-406 Kielce, Poland

e-mail: zmig@ujk.edu.pl

A. Migaszewski

Hydrogeotechnika, 262A Ściegiennego St., 25-116 Kielce, Poland

S. Hałas · A. Trembaczowski

Maria Curie-Skłodowska University, 1 Maria Curie-Skłodowska Sq., 20-031 Lublin, Poland 
state with water, varying from -1.44 to 3.05 and from -3.42 to 6.04 , respectively. This evidence matches well with the obtained mineralogical results.

Keywords Water ponds $\cdot \mathrm{S}, \mathrm{O}$ and $\mathrm{H}$ isotopes - Trace metals - Sediment mineralogy · Pyrite oxidation $\cdot$ Sulfate reduction $\cdot$ Sulfate pathways $\cdot$ Poland

\section{Introduction}

Acid mine drainage (AMD) is typically produced by the weathering of pyrite, marcasite $\left(\mathrm{FeS}_{2}\right)$ and other iron-bearing sulfides brought to the surface by mining, mineral processing or other human activity (e.g., Taylor and Wheeler 1994; Plumlee et al. 1999; Knöller et al. 2004; Edraki et al. 2005; Butler 2007; Nordstrom 2009, 2011a, b; Szynkiewicz et al. 2011). In contrast, acid rock drainage (ARD) occurs in oxidizing surficial environments when unmined sulfide ore deposits or mineralized rock weather; the sulfides may outcrop at the surface or be exposed by natural erosion or landslides. Some authors use a collective term AMD or acid drainage (AD) when describing both naturally and anthropogenically induced processes (e.g., Taylor and Wheeler 1994; Nordstrom 2009). The ARD is the source of acidification ( $\mathrm{pH}$ below 5 ) and may be associated with the release of sulfates and potentially deleterious metals into the environmental, in particular into waters, sediments, soils, wetlands and biota (e.g., Runkel et al. 2007; Cravotta III 2008a, b; Cánovas et al. 2008; Cidu et al. 2009; Mighanetara et al. 2009; Nordstrom 2009, 2011a, b).

The oxidation of pyrite or marcasite and subsequent conversion to sulfuric acid occurs through several reactions, with simplified equations as follows:

$$
\begin{gathered}
\mathrm{FeS}_{2}+7 / 2 \mathrm{O}_{2}+\mathrm{H}_{2} \mathrm{O} \rightarrow \mathrm{Fe}^{2+}+2 \mathrm{SO}_{4}^{2-}+2 \mathrm{H}^{2+} \\
\mathrm{Fe}^{2+}+1 / 4 \mathrm{O}_{2}+\mathrm{H}^{+} \rightarrow \mathrm{Fe}^{3+}+1 / 2 \mathrm{H}_{2} \mathrm{O} \\
\mathrm{Fe}^{3+}+3 \mathrm{H}_{2} \mathrm{O} \rightarrow \mathrm{Fe}(\mathrm{OH})_{3} \downarrow+3 \mathrm{H}^{+} \\
\mathrm{FeS}_{2}+14 \mathrm{Fe}^{3+}+8 \mathrm{H}_{2} \mathrm{O} \rightarrow 15 \mathrm{Fe}^{2+}+2 \mathrm{SO}_{4}^{2-}+16 \mathrm{H}^{+}
\end{gathered}
$$

Ferrous iron $\left(\mathrm{Fe}^{2+}\right)$ released as a result of reaction (1) undergoes oxidation to ferric iron $\left(\mathrm{Fe}^{3+}\right)$, which can either be hydrolyzed and form ferric hydroxide $\mathrm{Fe}(\mathrm{OH})_{3}$ (or mixtures of iron oxyhydroxides and oxyhydrosulfates) or can oxidize pyrite generating $\mathrm{Fe}^{2+}, \mathrm{SO}_{4}{ }^{2-}$ and $\mathrm{H}^{+}$ions, according to reaction (4). The oxidation of pyrite is initiated by reaction (1) at a $\mathrm{pH}$ of about 6 due to the low solubility of ferric ion. As a result of this reaction, the $\mathrm{pH}$ decreases to below 3 triggering the consecutive reaction (4). These processes are catalyzed primarily by iron-oxidizing bacterium species Acidithiobacillus ferrooxidans or A. thiooxidans, increasing reaction rates by several orders of magnitude (Nordstrom and Southam 1997). In the presence of other sulfides, these oxidation products (1-4) initiate a chain of reactions releasing various elements into the environment. The pyrite remains completely unreacted if it occurs in an oxygen-depleted environment, for example beneath the water table. However, some glacier studies suggest that sulfide oxidation might be very efficient under limited oxygen condition due to microbial activity (e.g., Wadham et al. 2004).

The principal objective of this investigation was to pinpont sources and transformations of dissolved sulfates in two water bodies located in the village of Marczakowe Doły outside the Wiśniówka mining area, and to find any geochemical relationship between them and the Podwiśniówka acid pit pond (Migaszewski et al. 2007, 2008) in the context of geologic setting of the study area (Holy Cross Mountains, south-central Poland). The 
novelty goal was to gain a better understanding of the biogeochemical sulfur cycle in two different AMD ponds and to use stable sulfur, oxygen and hydrogen isotope ratios and some trace metals for assessing any hydrologic relationship between the three ponds examined. This study was also undertaken to determine contamination of freshwater in a fish pond which is recharged by a neighboring farmer's well. To solve the principal objective, four types of study were performed: (1) field measurements of $\mathrm{pH}, \mathrm{EC}$ (electric conductivity), $\mathrm{T}, \mathrm{SO}_{4}{ }^{2-}, \mathrm{Fe}^{2+}$, and $\mathrm{Fe}^{3+}$ in waters, (2) determinations of dissolved $\mathrm{As}, \mathrm{Ca}$, $\mathrm{Cu}, \mathrm{Mg}, \mathrm{Mn}$ and $\mathrm{Zn}$ concentrations in waters, (3) identification of mineral phases in sediments of both acid ponds and (4) determinations of $\mathrm{S}$ and $\mathrm{O}$ stable isotopes in $\mathrm{SO}_{4}{ }^{2-}$ and $\mathrm{O}$ and $\mathrm{H}$ isotopes in $\mathrm{H}_{2} \mathrm{O}$.

The study area with three ponds of different chemistry represents high local hydrogeochemical variability and may serve as a field laboratory for studying acid rock drainage processes in the vicinity of mining areas.

\section{Study Area Location and Geologic Framework}

The study area is within Podwiśniówka Mt. located 5 km north of Kielce (Fig. 1) and is in the easternmost part of the large dismembered Wiśniówka massif which forms the western part of the Łysogóry Block in the Holy Cross Mountains. This Paleozoic structure is a part of the Trans-European Suture Zone. The highly complex geologic setting of the study area has been the subject of much controversy among structural geologists and paleontologists (e.g., Żylińska et al. 2006 and references therein). The Podwiśniówka Mt. bedrock consists of the Upper Cambrian (Furongian) series composed of quartzites, quartzitic sandstones with clayey shale, tuff/tuffite and bentonite interbeds. These rocks make up the Wiśniówka Sandstone Formation. Żylińska et al. (2006) suggested that the rocks from Podwiśniówka might be of uppermost Middle Cambrian age. The northern, eastern and western foot of Podwiśniówka Mt. is covered by Pleistocene tills, sands and loesses.

There is an abandoned mine pit at the summit of the Podwiśniówka Mount, which is partly filled with a shallow acid pond of about $150 \times 80 \mathrm{~m}$ in size and in places $1.5 \mathrm{~m}$ deep. This pond is located about $410 \mathrm{~m}$ above sea level. In the central part of the western wall of the quarry, a pyrite zone crops out. This mineralization zone extends eastward and partly crops out on the opposite lower wall. It consists of pyrite-quartz veins and quartzitequartz-pyrite tectonic breccias. The pyrite is crypto- to microcrystalline and contains a substantial isomorphic admixture of arsenic (average $1 \%$, in places up to $14 \%$, unpubl. data). The physical and chemical properties of the pyrite favor rapid weathering and generation of strongly acid waters. Another distinctive feature of this site is a lack of other associated sulfides and buffering gangue minerals and host rocks. This specific mineralogy and lithology create a unique acid pit pond with a low $\mathrm{pH}$ and exceptionally low concentrations of $\mathrm{SO}_{4}{ }^{2-}, \mathrm{Fe}^{2+}, \mathrm{Fe}^{3+}$ and trace elements (Migaszewski et al. 2007, 2008).

About 500 m east of the Podwiśniówka quarry in the village of Marczakowe Doły, there is another acid pond that occupies a dugout hole of about $10 \mathrm{~m}$ in diameter and $1.6 \mathrm{~m}$ deep. Its water is mostly light brown as opposed to clear water of the Podwiśniówka pit pond. A rivulet that flows out of this small pond is veneered with yellow-to-brown iron oxyhydroxides and oxyhydrosulfates. In addition, a fish pond of about $15 \mathrm{~m}$ in diameter and $1-\mathrm{m}$ deep discharged from a nearby slope spring is located around $100 \mathrm{~m}$ north of the Marczakowe Doły acid pond. The fish pond is drained by a rivulet devoid of any ochreous precipitates. Both ponds are not located on the same elevation: the acid pond is situated at 


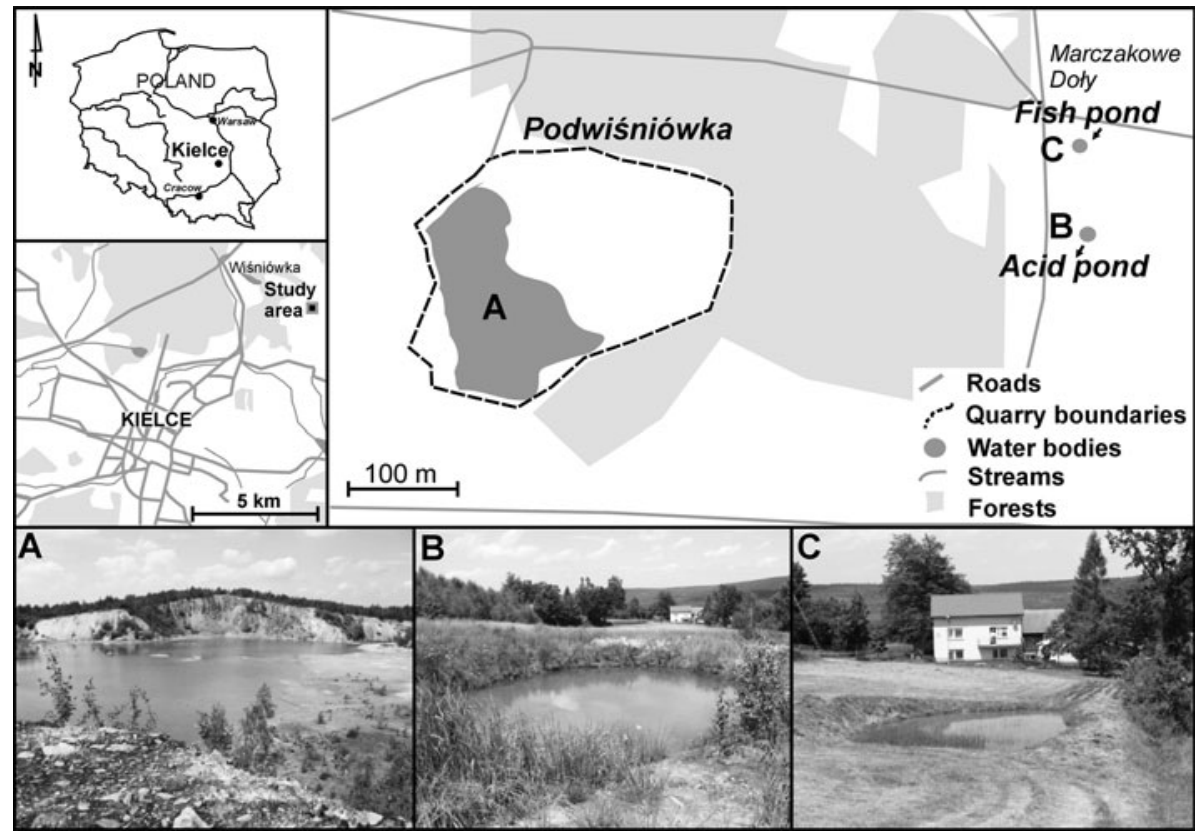

Fig. 1 Location site map of a Podwiśniówka acid pit pond, b Marczakowe Doły acid pond and c Marczakowe Doły fish pond

an elevation of about $370 \mathrm{~m}$ above sea level, whereas the fish pond lies a few meters below. The geology is the same as in the mine pit area. Moreover, there is no evidence of sulfides or sulfates such as gypsum in the vicinity of these two ponds. Both ponds have not been included in the scope of previous investigations (Migaszewski et al. 2007, 2008).

The three ponds examined are not hydrologically connected. The Podwiśniówka acid pit pond is fed by precipitation (rainfall and snowmelt). This results in seasonal fluctuations of its water level and temperature. In contrast, the two Marczakowe Doły ponds are located near the foot of the mount and are fed from separate perched aquifers. Both ponds are generally not affected by annual variations in precipitation.

\section{Methods and Materials}

\subsection{Field Geochemical Measurements and Sampling}

Fieldwork was performed during six sampling campaigns from June 8 of 2010 through March 25 of 2011 (Table 1). Direct measurements of pH, electric conductivity (EC) and temperature (T) of water, using a $\mathrm{pH}$ meter CP-105 and an EC-meter CC-101 equipped with a temperature sensor (Elmetron, Poland), were conducted. In addition, concentrations of $\mathrm{SO}_{4}{ }^{2-}, \mathrm{Fe}^{2+}$ and $\mathrm{Fe}^{3+}$ were determined on-site using a field spectrophotometer LF-205 (Slandi, Poland). The content of $\mathrm{Fe}^{3+}$ was calculated as the difference between $\mathrm{Fe}_{\text {total }}$ and $\mathrm{Fe}^{2+}$. Nine water samples were also collected in a period of December 15, 2010, through March 25, 2011, for determination of As, Ca, Cu, Fe, Mg, Mn and Zn (Table 2). A total of 14 water samples were collected for $\mathrm{S}, \mathrm{O}$ and $\mathrm{H}$ stable isotope measurements. 
Table 1 The $\mathrm{pH}, \mathrm{EC}, \mathrm{T}$ and concentrations of $\mathrm{Fe}^{2+}, \mathrm{Fe}^{3+}, \mathrm{SO}_{4}{ }^{2-}$ in the pond waters in June, 2010 through March, 2011

\begin{tabular}{|c|c|c|c|c|c|c|c|}
\hline Ponds & Parameters & $\begin{array}{l}\text { Jun. 8, } \\
2010\end{array}$ & $\begin{array}{l}\text { Jul. 16, } \\
2010\end{array}$ & $\begin{array}{l}\text { Sept. 30, } \\
2010\end{array}$ & $\begin{array}{l}\text { Nov. 12, } \\
2010\end{array}$ & $\begin{array}{l}\text { Dec. 15, } \\
2010\end{array}$ & $\begin{array}{l}\text { Mar. 25, } \\
2011\end{array}$ \\
\hline \multirow{6}{*}{$\begin{array}{l}\text { Marczakowe } \\
\text { Doły acid pond }\end{array}$} & $\mathrm{pH}$ & 2.8 & 3.3 & 2.4 & 2.9 & 3.6 & 3.5 \\
\hline & $\mathrm{EC}(\mu \mathrm{S} / \mathrm{cm})$ & 1,402 & 1,524 & 966 & 1,512 & 1,007 & 1,302 \\
\hline & $\mathrm{T}\left({ }^{\circ} \mathrm{C}\right)$ & 26 & 31 & 10 & 7 & 3 & 7 \\
\hline & $\mathrm{Fe}^{2+}(\mathrm{mg} / \mathrm{L})$ & 40 & 58 & 22 & 70 & 130 & 95 \\
\hline & $\mathrm{Fe}^{3+}(\mathrm{mg} / \mathrm{L})$ & 28 & 162 & 6 & 30 & $<0.1$ & $<0.1$ \\
\hline & $\mathrm{SO}_{4}^{2-}(\mathrm{mg} / \mathrm{L})$ & 731 & 965 & 295 & 785 & 785 & 792 \\
\hline \multirow{6}{*}{$\begin{array}{l}\text { Marczakowe } \\
\text { Doły fish pond }\end{array}$} & $\mathrm{pH}$ & 5.8 & 6.5 & n.d. & 6.0 & 5.8 & 6.0 \\
\hline & $\mathrm{EC}(\mu \mathrm{S} / \mathrm{cm})$ & 208 & 327 & n.d. & 482 & 405 & 365 \\
\hline & $\mathrm{T}\left({ }^{\circ} \mathrm{C}\right)$ & 22 & 32 & n.d. & 9 & 5 & 8 \\
\hline & $\mathrm{Fe}^{2+}(\mathrm{mg} / \mathrm{L})$ & $<0.1$ & $<0.1$ & n.d. & $<0.1$ & $<0.1$ & $<0.1$ \\
\hline & $\mathrm{Fe}^{3+}(\mathrm{mg} / \mathrm{L})$ & $<0.1$ & 0.3 & n.d. & $<0.1$ & $<0.1$ & $<0.1$ \\
\hline & $\mathrm{SO}_{4}^{2-}(\mathrm{mg} / \mathrm{L})$ & 70 & 104 & n.d. & 134 & 119 & 108 \\
\hline \multirow{6}{*}{$\begin{array}{l}\text { Podwiśniówka } \\
\text { acid pit pond }\end{array}$} & $\mathrm{pH}$ & 2.7 & 2.8 & 1.8 & 1.8 & 2.8 & 3.1 \\
\hline & $\mathrm{EC}(\mu \mathrm{S} / \mathrm{cm})$ & 610 & 929 & 789 & 981 & 817 & 643 \\
\hline & $\mathrm{T}\left({ }^{\circ} \mathrm{C}\right)$ & 26 & 31 & 10 & 9 & 3 & 7 \\
\hline & $\mathrm{Fe}^{2+}(\mathrm{mg} / \mathrm{L})$ & 6.0 & 2.9 & 0.9 & 2.4 & 0.8 & 2.9 \\
\hline & $\mathrm{Fe}^{3+}(\mathrm{mg} / \mathrm{L})$ & 7.5 & 8.1 & 9.5 & 7.2 & 8.5 & 8.0 \\
\hline & $\mathrm{SO}_{4}^{2-}(\mathrm{mg} / \mathrm{L})$ & 134 & 196 & 106 & 115 & 111 & 108 \\
\hline
\end{tabular}

n.d. Not determined

The water samples were filtered through $0.45-\mu \mathrm{m}$-pore-size filters. A set of water samples included one blank (deionized water from the laboratory that was processed in the field along with the environmental samples) and one replicate sample for each sampling campaign. Filtered water samples were immediately transported to the Geochemical Laboratory of the Institute of Chemistry, Jan Kochanowski University in Kielce and stored in a refrigerator at a temperature of about $4-6{ }^{\circ} \mathrm{C}$. The chemical analysis was performed on the following day.

In addition, three sediment samples were collected for scanning electron microscope (SEM) and X-ray diffraction (XRD) studies: two samples at a depth of 0-2 and 5-7 cm from the Marczakowe Doły acid pond and one surface sediment sample from the Podwiśniówka acid pit pond.

During sample collection, transport and storage, procedures were followed to minimize the possibility of contamination.

\subsection{Chemical Analysis}

All the samples were analyzed for $\mathrm{As}, \mathrm{Ca}, \mathrm{Cu}, \mathrm{Fe}, \mathrm{Mg}, \mathrm{Mn}$ and $\mathrm{Zn}$, using an ICP-MS instrument (model ELAN DRC II, Perkin Elmer). Operating conditions were as follows: sweeps/reading - 20, readings/replicate-3, replicates - 4, nebulizer gas flow- $0.99 \mathrm{~L} / \mathrm{min}$, plasma gas flow-1.5 L/min, lens voltage-6.50 V, plasma power-1,275 W. The ICPMS instrument was optimized with a standard daily procedure. For trace element determination, a set of Multielement Calibration Standard 3 Perkin Elmer solutions (0.1, 1.0, 
Table 2 Concentrations of selected trace elements in the pond waters in December 2010 through March 2011

\begin{tabular}{lllll}
\hline Ponds & Elements & Dec. 15, 2010 & Feb. 23, 2011 & Mar. 25, 2011 \\
\hline Marczakowe Doły acid pond & $\mathrm{Ca}(\mathrm{mg} / \mathrm{L})$ & 37.3 & 211.7 & 6.1 \\
& $\mathrm{Fe}_{\text {total }}(\mathrm{mg} / \mathrm{L})$ & $130.0^{\mathrm{a}}$ & 244.5 & $95.0^{\mathrm{a}}$ \\
& $\mathrm{Mg}(\mathrm{mg} / \mathrm{L})$ & 16.0 & 24.2 & 4.8 \\
& $\mathrm{As}(\mu \mathrm{g} / \mathrm{L})$ & 83.1 & 589.4 & 275.9 \\
& $\mathrm{Cu}(\mu \mathrm{g} / \mathrm{L})$ & 72.2 & 0.5 & 4.0 \\
& $\mathrm{Mn}(\mu \mathrm{g} / \mathrm{L})$ & 483.6 & 455.8 & 531.9 \\
& $\mathrm{Zn}(\mu \mathrm{g} / \mathrm{L})$ & 300 & 190 & 30 \\
Marczakowe Doły fish pond & $\mathrm{Ca}(\mathrm{mg} / \mathrm{L})$ & 12.3 & 46.8 & 1.7 \\
& $\mathrm{Fe}(\mathrm{mg} / \mathrm{L})$ & $<0.1$ & $<0.1$ & $<0.1$ \\
& $\mathrm{Mg}(\mathrm{mg} / \mathrm{L})$ & 7.0 & 7.6 & 1.9 \\
& $\mathrm{As}(\mu \mathrm{g} / \mathrm{L})$ & 52.0 & 17.5 & 25.7 \\
& $\mathrm{Cu}(\mu \mathrm{g} / \mathrm{L})$ & 66.4 & $<0.1$ & 6.3 \\
& $\mathrm{Mn}(\mu \mathrm{g} / \mathrm{L})$ & 224.3 & 88.5 & 130.2 \\
& $\mathrm{Zn}(\mu \mathrm{g} / \mathrm{L})$ & 0.20 & 0.15 & 0.03 \\
Podwiśniówka acid pit pond & $\mathrm{Ca}(\mathrm{mg} / \mathrm{L})$ & 1.4 & 8.4 & 0.1 \\
& $\mathrm{Fe}(\mathrm{mg} / \mathrm{L})$ & 9.3 & 19.4 & 10.9 \\
& $\mathrm{Mg}(\mathrm{mg} / \mathrm{L})$ & 0.8 & 1.5 & 0.2 \\
& $\mathrm{As}(\mu \mathrm{g} / \mathrm{L})$ & 42.8 & 23.0 & 26.6 \\
& $\mathrm{Cu}(\mu \mathrm{g} / \mathrm{L})$ & 103.8 & 70.6 & 75.0 \\
$\mathrm{Mn}(\mu \mathrm{g} / \mathrm{L})$ & 149.4 & 161.0 & 92.4 \\
$\mathrm{Zn}(\mu \mathrm{g} / \mathrm{L})$ & 100 & 100 & 40 \\
\hline
\end{tabular}

${ }^{\mathrm{a}} \mathrm{Fe}^{2+}$ concentrations

and $10 \mathrm{mg} / \mathrm{L}$ ) were applied. The standard reference materials (SRM) applied for measuring element concentrations in the samples were NIST-1640a and NIST 1643e. Quality control included both accuracy (SRM) and precision (triplicates). The average recovery of elements from the SRM was 90-99\%, and the uncertainty of the method was below $10 \%$.

The results of the chemical analyses were used for calculating saturation indices (SI) for minerals using the PHREEQC program for Windows version 2.12.02 (Parkhurst and Apello 1999). The PHREEQC database was supplemented with thermodynamic data for schwertmannite and 6-line ferrihydrite (Majzlan et al. 2004) and hydroxy-green rusts (Bourrié et al. 1999). The saturation index is defined as: $\mathrm{SI}=\log \left(\mathrm{IAP} / \mathrm{K}_{\mathrm{sp}}\right)$, where IAP is ion activity product and $\mathrm{K}_{\mathrm{sp}}$ is the solubility product for a given temperature. This means that when IAP $=\mathrm{K}_{\mathrm{sp}}$, then $\mathrm{SI}=0$ and water is at thermodynamic equilibrium with respect to the mineral. When SI $>0$, water is supersaturated in relation to the mineral and this mineral may potentially precipitate. In contrast, if SI $<0$, water is undersaturated with respect to the mineral, this mineral may potentially dissolve.

\subsection{Mineralogical Study}

Identification of mineral phases in three sediment samples collected from the Marczakowe Doły acid pond and the Podwiśniówka acid pit pond was performed with SEM and XRD. 
Microscopic studies were performed with a scanning electron microscope Hitachi S-4700 (signal A = SEI, magn. = 4,500-20,000', EHT $=20.0 \mathrm{kV}$ ) and a Bruker axs D8 Advance transmission $\mathrm{X}$-ray powder diffractometer (CoK $\alpha$ radiation, $3-76^{\circ} 2 \theta$ scan range, $0.02 \mathrm{deg} / \mathrm{step}$, current $35 \mathrm{kV}, 40 \mathrm{~mA}$ ). The SEM and XRD determinations were performed at the Institute of Geological Sciences, Jagiellonian University in Cracow and the Institute of Geological Sciences of the Polish Academy of Sciences in Warsaw, respectively.

\subsection{Sample Preparation and Isotope analysis}

The sample preparation and stable $\mathrm{S}, \mathrm{O}$ and $\mathrm{H}$ isotope measurements were performed at the Mass Spectrometry Laboratory of Maria Curie-Skłodowska University in Lublin. $\mathrm{SO}_{4}{ }^{2-}$ ions were precipitated in the form of $\mathrm{BaSO}_{4}$ by adding $10 \% \mathrm{BaCl}_{2}$ solution. The precipitated $\mathrm{BaSO}_{4}$ was rinsed with deionized water to remove chloride ions (until a negative reaction with $\mathrm{AgNO}_{3}$ was obtained) and dried at $100-110{ }^{\circ} \mathrm{C}$. The $\mathrm{SO}_{2}$ gas for $\mathrm{S}$ isotope determinations was extracted from sulfates by reacting with a mixture of $\mathrm{NaPO}_{3}$ and $\mathrm{Cu}_{2} \mathrm{O}$ (3:4) under vacuum at $800{ }^{\circ} \mathrm{C}$ in a boat made of copper foil (Hałas and Szaran 2004). The obtained $\mathrm{SO}_{2}$ was cryogenically separated from $\mathrm{CO}_{2}$ in $n$-pentane frozen in liquid nitrogen and from water vapor in a mixture of dry ice and acetone (Mizutani and Oana 1973; Kusakabe 2005). $\mathrm{CO}_{2}$ for $\mathrm{O}$ isotope determinations was obtained by reducing $\mathrm{BaSO}_{4}$ with graphite to $\mathrm{CO}$ which subsequently was quantitatively converted to $\mathrm{CO}_{2}$ by glow discharge in magnetic field (Hałas et al. 2007). This is a modified method of Mizutani (1971).

The stable $\mathrm{S}$ and $\mathrm{O}$ isotope determinations were carried out off-line on a dual inlet and triple collector isotope ratio-modified mass spectrometer MI-1305 with modified inlet and detection systems on $\mathrm{SO}_{2}$ and $\mathrm{CO}_{2}$ gases, respectively. The results were given as $\delta^{34} \mathrm{~S}$ values relative to V-CDT (Vienna Cañon Diablo Troilite) and $\delta^{18} \mathrm{O}$ values relative to V-SMOW (Vienna Standard Mean Ocean Water), and reported in \%o. International standard NBS-127 standard $\delta^{34} \mathrm{~S}=21.17 \%$ and $\delta^{18} \mathrm{O}=8.73 \%$ [as determined at Mass Spectrometry Laboratory, Maria Curie-Skłodowska University (Hałas et al. 2007)] was analyzed for normalization of raw delta values. Sulfur isotope determinations in sulfates were performed with a precision of $\pm 0.08 \%$, whereas $\delta^{18} \mathrm{O}$ attained precision of $\pm 0.05 \%$. The reproducibility $(2 \sigma)$ obtained for complete analysis of replicate aliquots of standards and samples was $0.2 \%$.

In addition, 14 water samples were analyzed for stable $\mathrm{O}$ and $\mathrm{H}$ isotope ratios. The water samples were filtrated and analyzed automatically along with two IAEA standards, $\mathrm{OH}-13$ and $\mathrm{OH}-16$, to which both delta values of the analyzed samples were normalized and expressed in \%o versus V-SMOW. The following delta values were accepted for the IAEA standard $\mathrm{OH}-13 \delta^{18} \mathrm{O}=-1.28 \%$ and $\delta \mathrm{D}=-2.67 \%$, whereas for OH-16 standard: $\delta^{18} \mathrm{O}=-15.57 \%$ and $\delta \mathrm{D}=-120.67 \%$ (Choudhry et al. 2011). The analytical reproducibility $(2 \sigma)$ was $0.1 \%$ for $\mathrm{O}$ and $1 \%$ for $\mathrm{H}$. The $\delta^{18} \mathrm{O}$ and $\delta \mathrm{D}$ values of water samples were determined online on the Picarro L2120-i Analyzer in the Faculty of Geosciences, Maria Curie-Skłodowska University in Lublin.

\section{Results and Discussion}

\subsection{Sediment Mineralogy}

The surface brownish-yellow precipitate derived from the Marczakowe Doły acid pond revealed the presence of characteristic monominerallic schwertmannite $\mathrm{Fe}_{8} \mathrm{O}_{8}(\mathrm{OH})_{6} \mathrm{SO}_{4}$ 
(Bigham et al. 1996) showing "pin cushion" morphology (Fig. 2a). In contrast, the yellow-brown subsurface precipitate lacked this mineral and was composed of quartz, smectite with mixed-layered illite-smectite and iron oxyhydroxides, that is, goethite $\alpha$-FeOOH and presumably ferrihydrite $\sim \mathrm{Fe}(\mathrm{OH})_{3} \cdot 1.8 \mathrm{H}_{2} \mathrm{O}$ (Fig. 2C). The mineralogical composition of this ochreous precipitate is characteristic of AMD/ARD sites throughout the world (Edraki et al. 2005). At least three minerals, for example, schwertmannite, ferrihydrite and goethite play a significant role in controlling a $\mathrm{pH}$ of pond and lake waters as well as sorption/desorption of trace elements (e.g., Bigham et al. 1990, 1994; Schwertmann et al. 1995; Regenspurg et al. 2004; Acero et al. 2006). Schwertmannite forms through bacterially catalyzed oxidation of $\mathrm{Fe}^{2+}$ in a $\mathrm{pH}$ range of $2.8-4.5$ and at $\mathrm{SO}_{4}{ }^{2-}$ concentrations of 1,000-3,000 mg/L (Bigham et al. 1994, 1996).

The Podwiśniówka acid pit pond sediment, in turn, was comprised of quartz, illite, chlorite and kaolinite with some admixture of jarosite $\left(\mathrm{H}_{3} \mathrm{O}, \mathrm{K}, \mathrm{Na}\right) \mathrm{Fe}_{3}{ }^{3+}\left[\left(\mathrm{SO}_{4}\right)_{2}(\mathrm{OH})_{6}\right]$ and probably subordinate fougérite (known formerly as green rusts) $\left(\mathrm{Fe}^{2+}, \mathrm{Mg}\right)_{6}\left(\mathrm{Fe}^{3+}\right)_{2}$ $(\mathrm{OH})_{18} \cdot 4 \mathrm{H}_{2} \mathrm{O}$ and mixed-layered illite-smectite (Fig. 2c). The mineral inventory of this pond sediment reflects a more acidic environment. Jarosite is a product of bacterially induced pyrite oxidation and typically occurs at oxic-anoxic interfaces at the $\mathrm{pH} \leq 2.8$ (Bigham et al. 1996). It should be mentioned that the largest accumulations of secondary jarosite were also found on decomposed pyrite surfaces (Fig. 2b).

\subsection{Geochemistry of Pond Waters}

Of the three ponds examined, the chemistry of the Marczakowe Doły acid pond is unique with a low $\mathrm{pH}$ (2.4-3.6) and simultaneously high concentrations of $\mathrm{SO}_{4}{ }^{2-}$ (295-965 mg/L), total Fe (28-244.5 mg/L), As (83.1-589.4 $\mu \mathrm{g} / \mathrm{L})$ and Mn (455.8-531.9 mg/L) (Tables 1, 2), which are characteristic of AMD or ARD waters (e.g., Banks et al. 1997; Smedley and Kinniburgh 2002; Druschel et al. 2004; Bednar et al. 2005; Nordstrom 2011a, b). Except for July 16 of 2010, the predominance of $\mathrm{Fe}^{2+}(22-130 \mathrm{mg} / \mathrm{L})$ over $\mathrm{Fe}^{3+}(0-30 \mathrm{mg} / \mathrm{L})$ is likely due to precipitation of brownish-yellow schwertmannite (Fig. 2a). This mineral occurs in the form of colloids that impart mostly brownish-yellow color to water and fresh sediment. In contrast, the Podwiśniówka acid pit pond has lower concentrations of sulfates and most traces metals compared to the Marczakowe Doły acid pond. Except for the low $\mathrm{pH}$ (1.8-3.3), this chemistry generally is not similar to other AMD/ARD-influenced waters (Migaszewski et al. 2007, 2008).

Except for July 16 of 2010 , the predominance of $\mathrm{Fe}^{2+}(22-130 \mathrm{mg} / \mathrm{L})$ over $\mathrm{Fe}^{3+}$ $(0-30 \mathrm{mg} / \mathrm{L})$ in the Marczakowe Doły acid pond water is likely due to precipitation of schwertmannite (Fig. 2a). The lowest concentrations of $\mathrm{Fe}^{3+}(<0.1 \%)$ at the $\mathrm{pH} 3.5-3.6$ were noted on December 15 of 2010 and March 25 of 2011. The Podwiśniówka acid pit pond water displayed, in turn, no distinct variations of the iron species concentrations. This characteristic and the predominance of $\mathrm{Fe}^{3+}$ over $\mathrm{Fe}^{2+}$ may suggest a more stable redox environment in this larger pond. In addition, the lower $\mathrm{pH}(\leq 2.8)$ favors precipitation of jarosite (Fig. 2b).

There is no significant correlation $(P<0.05)$ between different hydrogeochemical parameters, particularly between the $\mathrm{pH}$ and $\mathrm{SO}_{4}{ }^{2-}$ concentrations. A somewhat higher correlation coefficient $\left(r^{2}=0.58\right)$ is observed only between $\mathrm{SO}_{4}{ }^{2-}$ and $\mathrm{Fe}^{2+}$ concentrations in the Marczakowe Doły acid pond water. The higher $\mathrm{pH}$ and concentrations of $\mathrm{SO}_{4}{ }^{2-}$, As, total $\mathrm{Fe}$, and $\mathrm{Mn}$ of the Marczakowe Doły acid pond suggest that there is no hydraulic connection with the Podwiśniówka acid pit pond. 


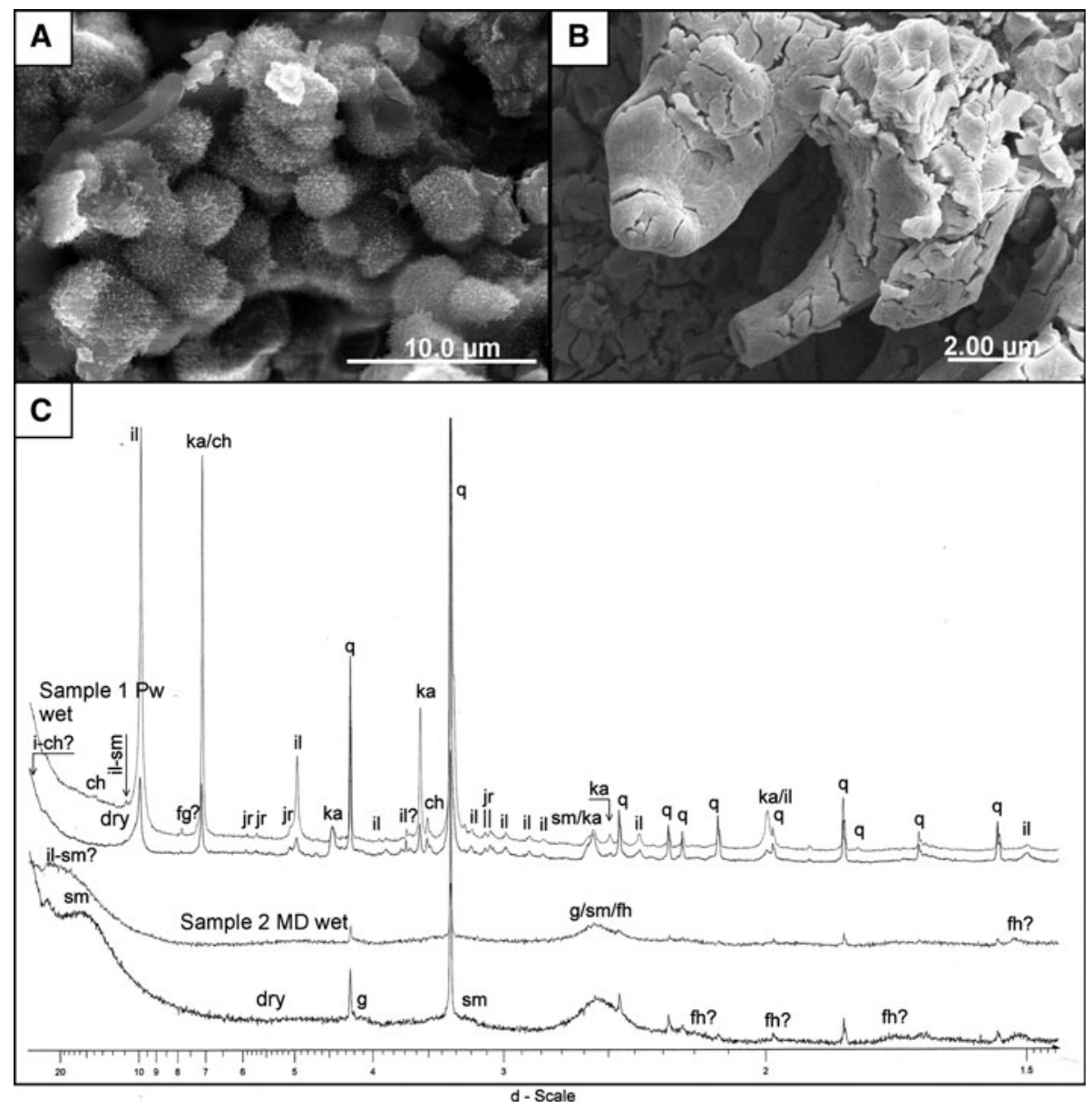

Fig. 2 a, b SEM images of "pin cushion" schwertmannite taken from the surficial ochreous precipitate $(0-2 \mathrm{~cm})$ and c X-ray diffraction patterns for Podwiśniówka pit pond sediment (sample $1 \mathrm{Pw})$ and Marczakowe Doły acid pond precipitate (sample $2 \mathrm{MD}$; depth 5-7 cm). $q$ quartz, $g$ goethite, $s m$ smectite, $f h$ ferrihydrite?, $\mathrm{jr}$ jarosite, $\mathrm{fg}$ fougérite?, $\mathrm{ka}$ kaolinite, $i l$ illite, $\mathrm{ch}$ chlorite

The Marczakowe Doły fish pond had a distinctly higher pH (5.8), which might be brought about by the local presence of calcite-rich loess-reworked deposits showing acidbuffering properties. It is noteworthy that this pond contained similar concentrations of $\mathrm{SO}_{4}{ }^{2-}(70-134 \mathrm{mg} / \mathrm{L})$ and As $(17.5-52.0 \mu \mathrm{g} / \mathrm{L})$ to the Podwiśniówka acid pit pond (106-196 and 23-42.8 mg/L, respectively). However, the $\mathrm{Fe}^{2+}$ and $\mathrm{Fe}^{3+}$ contents were below detection limits for a given analytical method $(<0.1 \mathrm{mg} / \mathrm{L})$. This may indicate a common source of $\mathrm{SO}_{4}{ }^{2-}$ and As for both ponds, as well as oxidation and precipitation of iron at the higher $\mathrm{pH}$ in a groundwater circulation system.

The chemical analyses also indicated that the $\mathrm{pH}, \mathrm{EC}$ and concentrations of $\mathrm{SO}_{4}{ }^{2-}$, $\mathrm{Fe}^{2+}, \mathrm{Fe}^{3+}$, $\mathrm{As}, \mathrm{Ca}, \mathrm{Mg}$ and $\mathrm{Mn}$ in the pond waters exhibited seasonal variations, with the greatest fluctuations in the Marczakowe Doły acid pond water (Tables 1, 2). This variability is primarily due to sorption/desorption processes related to formation of schwertmannite and transformation of this mineral into ferrihydrite and goethite (Majzlan et al. 
2004; Acero et al. 2006) as evidenced by mineralogy of surface (fresh) and subsurface (old) sediment (Fig. 2). Laboratory experiments on synthetic schwertmannite showed that it normally underwent transformation to more crystalline ferrihydrite and goethite, releasing trace metals to water (Bigham et al. 1996).

Tables 3 and 4 summarize the selected mineral saturation indices (SI) computed for each water sample from two acid ponds. The saturation indices indicated that schwertmannite and nanosized $\varepsilon-\mathrm{Fe}_{2} \mathrm{O}_{3}\left(\mathrm{Fe}^{3+}\right.$ oxide polymorph) were closest to thermodynamic equilibrium state with water, varying from -1.44 to 3.05 and from -3.42 to 6.04 , respectively. The only exception was the Marczakowe Doły acid pond where on December 15 of 2010 and March 25 of 2011, these minerals likely did not precipitate due to the lack of $\mathrm{Fe}^{3+}$ ions. The supersaturation of hematite $(\mathrm{SI}=5.29-14.74)$ should not be used as direct evidence that hematite is going to precipitate from these solutions because it may form as a result of transformation of goethite over longer time scales and specific conditions. The remaining constituents, especially 2- and 6-line ferrihydrite (SI below -10.19) and hydroxy-green rusts (SI below -18.03), should dissolve. The extremely negative SI values (below -52.79) for gaseous oxygen were an indication of its depletion in water. Gypsum and anhydrite with SI in the range of -1.24 to -4.49 were somewhat undersaturated in both acid ponds. The selected phases displayed seasonal variations during the study period. In general, there were no distinct differences in mineral SI between the water samples collected from two acid ponds.

\section{$4.3 \mathrm{~S}$ and $\mathrm{O}$ Isotopes of Sulfates}

The results of $\delta^{34} \mathrm{~S}_{-} \mathrm{SO}_{4}{ }^{2-}$ and $\delta^{18} \mathrm{O}-\mathrm{SO}_{4}{ }^{2-}$ as well as $\delta^{18} \mathrm{O}_{\mathrm{V}-\mathrm{SMOW}}-\mathrm{H}_{2} \mathrm{O}$ and $\delta \mathrm{D}_{\mathrm{V}-\mathrm{SMOw}}-$ $\mathrm{H}_{2} \mathrm{O}$ values in waters are reported in Table 5. Both acid ponds had similar $\delta^{34} \mathrm{~S}$ and $\delta^{18} \mathrm{O}$ values in dissolved sulfate. The Podwiśniówka acid pit pond water exhibited the $\delta^{34} \mathrm{~S}-$ $\mathrm{SO}_{4}{ }^{2-}$ and $\delta^{18} \mathrm{O}-\mathrm{SO}_{4}{ }^{2-}$ values in the range of -16.2 to $-11.5 \%$ (mean of $-13.6 \%$ ) and -5.0 to $-3.3 \%$ (mean of $-3.9 \%$ ), respectively. Nearly the same ranges of $\delta^{34} \mathrm{~S}_{-} \mathrm{SO}_{4}{ }^{2-}$ $(-15.6$ to $-13.9 \%)$ and $\delta^{18} \mathrm{O}-\mathrm{SO}_{4}{ }^{2-}(-8.1$ to $-3.2 \%$ ) with a mean of -14.6 and $-5.9 \%$ were noted in the Marczakowe Doły acid pond water. The $\delta^{34} \mathrm{~S}_{-} \mathrm{SO}_{4}{ }^{2-}$ and $\delta^{18} \mathrm{O}-$ $\mathrm{SO}_{4}{ }^{2-}$ values of the Podwiśniówka pit pond water were similar to those $(-19.8$ to -11.1 and -3.8 to $+1.1 \%$, respectively) derived from the previous study (Migaszewski et al. 2008). In contrast, the Marczakowe Doły fish pond water exhibited lower $\delta^{34} \mathrm{~S}_{-} \mathrm{SO}_{4}{ }^{2-}$ values $\left(-11.6\right.$ to $-9.5 \%$ ), but nearly the same $\delta^{18} \mathrm{O}-\mathrm{SO}_{4}{ }^{2-}$ range $(-4.3$ to $-3.6 \%$ ). However, it should be stressed that these values from only two sampling times may have not captured same amount of variability as for the other ponds.

No statistically significant correlation was recorded between $\delta^{34} \mathrm{~S}_{-} \mathrm{SO}_{4}{ }^{2-}$ and $\mathrm{SO}_{4}{ }^{2-}$ concentrations $\left(r^{2}=0.24\right)$ or $\delta^{34} \mathrm{~S}_{-} \mathrm{SO}_{4}{ }^{2-}$ and $\delta^{18} \mathrm{O}-\mathrm{SO}_{4}{ }^{2-}\left(r^{2}=0.13\right)$, presumably due to mixing sulfates derived from different sulfate sources and sulfur transformation processes (Mayer 2006), for example, bacterially induced pyrite oxidation, bacterially (dissimilatory) dissolved sulfate reduction and partly CS-mineralization (see the Sect. 4.5). The only weak negative correlation $(P<0.05)$ was noted between $\delta^{18} \mathrm{O}_{-} \mathrm{SO}_{4}{ }^{2-}$ and $\mathrm{SO}_{4}{ }^{2-}$ concentrations $\left(r^{2}=0.64\right)$; an increase of $\mathrm{SO}_{4}{ }^{2-}$ concentration is coupled with more negative $\delta^{18} \mathrm{O}-\mathrm{SO}_{4}{ }^{2-}$ values.

\section{4 $\mathrm{O}$ and $\mathrm{H}$ Isotopes of Waters}

The $\delta^{18} \mathrm{O}-\mathrm{H}_{2} \mathrm{O}$ values in all three ponds examined varied from -11.3 to $-1.6 \%$. The most negative $\delta^{18} \mathrm{O}-\mathrm{H}_{2} \mathrm{O}$ (mean of $-11.2 \%$ ) occurred in the Marczakowe Doły fish pond 
Table 3 Saturation indices for selected minerals and oxygen in the Marczakowe Doły acid pond calculated with the PHREEQC program for Windows

\begin{tabular}{|c|c|c|c|c|c|c|}
\hline Phase & $\begin{array}{l}\text { Jun. 8, } \\
2010\end{array}$ & $\begin{array}{l}\text { Jul. 16, } \\
2010\end{array}$ & $\begin{array}{l}\text { Sept. 30, } \\
2010\end{array}$ & $\begin{array}{l}\text { Nov. 12, } \\
2010\end{array}$ & $\begin{array}{l}\text { Dec. 15, } \\
2010\end{array}$ & $\begin{array}{l}\text { Mar. 25, } \\
2011\end{array}$ \\
\hline Anhydrite & - & - & - & - & -1.46 & -2.22 \\
\hline$\varepsilon-\mathrm{Fe}_{2} \mathrm{O}_{3}$ & 1.91 & 6.04 & -1.01 & 2.49 & - & - \\
\hline $\mathrm{Fe}(\mathrm{OH})_{3}(\mathrm{a})$ & -1.59 & 0.48 & -3.05 & -1.30 & - & - \\
\hline 2-line ferrihydrite & -12.66 & -10.59 & -14.12 & -12.37 & - & - \\
\hline 6-line ferrihydrite & -12.26 & -10.19 & -13.72 & -11.97 & - & - \\
\hline Goethite & 4.30 & 6.37 & 2.84 & 4.59 & - & - \\
\hline Gypsum & - & - & - & - & -1.24 & -2.00 \\
\hline $\mathrm{H}_{2}(\mathrm{~g})$ & -13.60 & -14.60 & -12.80 & -13.80 & -15.20 & -15.00 \\
\hline Hausmannite & - & - & - & - & -40.52 & -41.23 \\
\hline Hematite & 10.61 & 14.74 & 7.70 & 11.20 & - & - \\
\hline Hydroxy-green rusts $\mathrm{Fe}_{3}(\mathrm{OH})_{8}$ & -25.91 & -21.52 & -29.51 & -24.42 & -18.03 & -19.26 \\
\hline Manganite & - & - & - & - & -15.97 & -16.24 \\
\hline Melanterite & -3.71 & -3.52 & -4.23 & -3.45 & -3.20 & -3.30 \\
\hline $\mathrm{O}_{2}(\mathrm{~g})$ & -55.99 & -53.99 & -57.59 & -55.59 & -52.79 & -53.19 \\
\hline Pyrochroite & - & - & - & - & -13.43 & -13.60 \\
\hline Pyrolusite & - & - & - & - & -24.41 & -24.78 \\
\hline Schwertmannite & 1.10 & 3.05 & -0.31 & 1.37 & - & - \\
\hline $\mathrm{Zn}(\mathrm{OH})_{2}(\mathrm{e})$ & - & - & - & - & -10.07 & -11.28 \\
\hline
\end{tabular}

water, and the least negative $\delta^{18} \mathrm{O}-\mathrm{H}_{2} \mathrm{O}$ (mean of $-6.6 \%$ ) were found in the Podwiśniówka acid pit pond water. The former value was relatively close to that (mean of $-10.3 \%$ ) recorded in the Marczakowe Doły acid pond. The $\delta \mathrm{D}-\mathrm{H}_{2} \mathrm{O}$ values for all three ponds were in the range of -80.7 to $-29.7 \%$ and reflected the same trend as the $\delta^{18} \mathrm{O}-$ $\mathrm{H}_{2} \mathrm{O}$ mean values: from $-80.6 \%$ (Marczakowe Doły fish pond) and $-75.2 \%$ (Marczakowe Doły acid pond) to $-56.6 \%$ (Podwiśniówka acid pit pond). In contrast to both Marczakowe Doły ponds, the Podwiśniówka acid pit pond revealed distinct seasonal variations in both $\delta^{18} \mathrm{O}-\mathrm{H}_{2} \mathrm{O}$ and $\delta \mathrm{D}-\mathrm{H}_{2} \mathrm{O}$ values. The water of these two acid ponds was strongly enriched both in ${ }^{18} \mathrm{O}$ and ${ }^{2} \mathrm{H}$ isotopes on July 16 of 2012 when the temperature of water raised to $32{ }^{\circ} \mathrm{C}$. For example, the $\delta^{18} \mathrm{O}-\mathrm{H}_{2} \mathrm{O}$ and $\delta \mathrm{D}-\mathrm{H}_{2} \mathrm{O}$ values were $-1.6 \%$ and $-29.7 \%$, respectively, in the Podwiśniówka acid pit pond, which are the least negative values reported for these two isotopes in water. The lower temperatures $\left(3^{\circ} \mathrm{C}\right)$ on December 15 results in more negative isotopic signatures. For example, the $\delta^{18} \mathrm{O}-\mathrm{H}_{2} \mathrm{O}$ and $\delta \mathrm{D}-\mathrm{H}_{2} \mathrm{O}$ values were -10.8 and $-77.4 \%$, respectively, in the Marczakowe Doły acid pond. The high correlation coefficient $\left(r^{2}=0.99\right)$ between $\delta{ }^{18} \mathrm{O}-\mathrm{H}_{2} \mathrm{O}$ and $\delta \mathrm{D}-\mathrm{H}_{2} \mathrm{O}$ values indicates atmospheric precipitation as the only source of water.

The statistically significant correlation $(P<0.05)$ also occurs between the $\delta^{18} \mathrm{O}$ or $\delta \mathrm{D}$ and temperature varying from 0.75 to 0.92 (Fig. 3 ). The same natural variation due to isotopic fractionation in rainwater or snowmelt was recorded in other studies (e.g., Mayo et al. 1992; Ingraham 1998; Hazen et al. 2002). The heavier isotope values in the water result from the evaporation of the lighter isotopes during warmer months (Hoefs 2009). The $\delta^{18} \mathrm{O}$ and $\delta \mathrm{D}$ isotope differences between the two acid ponds can be attributed 
Table 4 Saturation indices for selected minerals and oxygen in the Podwiśniówka acid pit pond calculated with the PHREEQC program for Windows

\begin{tabular}{|c|c|c|c|c|c|c|}
\hline Phase & $\begin{array}{l}\text { Jun. 8, } \\
2010\end{array}$ & $\begin{array}{l}\text { Jul. 16, } \\
2010\end{array}$ & $\begin{array}{l}\text { Sept. 30, } \\
2010\end{array}$ & $\begin{array}{l}\text { Nov. 12, } \\
2010\end{array}$ & $\begin{array}{l}\text { Dec. 15, } \\
2010\end{array}$ & $\begin{array}{l}\text { Mar. 25, } \\
2011\end{array}$ \\
\hline Anhydrite & - & - & - & - & -3.38 & -4.49 \\
\hline$\varepsilon-\mathrm{Fe}_{2} \mathrm{O}_{3}$ & 1.30 & 1.66 & -3.12 & -3.42 & 2.02 & 3.42 \\
\hline $\mathrm{Fe}(\mathrm{OH})_{3}(\mathrm{a})$ & -1.89 & -1.71 & -4.10 & -4.25 & -1.53 & -0.83 \\
\hline 2-line ferrihydrite & -12.96 & -12.78 & -15.17 & -15.32 & -12.60 & -11.90 \\
\hline 6-line ferrihydrite & -12.56 & -12.38 & -14.77 & -14.92 & -12.20 & -11.50 \\
\hline Goethite & 4.00 & 4.18 & 1.79 & 1.64 & 4.36 & 5.06 \\
\hline Gypsum & - & - & - & - & -3.16 & -4.27 \\
\hline $\mathrm{H}_{2}(\mathrm{~g})$ & -13.40 & -13.60 & -11.60 & -11.60 & -13.60 & -14.20 \\
\hline Hausmannite & - & - & - & - & -47.76 & -45.98 \\
\hline Hematite & 10.01 & 10.37 & 5.59 & 5.29 & 10.73 & 12.13 \\
\hline Hydroxy-green rusts $\mathrm{Fe}_{3}(\mathrm{OH})_{8}$ & -28.59 & -28.83 & -38.35 & -37.08 & -30.37 & -26.29 \\
\hline Manganite & - & - & - & - & -18.65 & -17.96 \\
\hline Melanterite & - & - & - & - & -5.91 & -5.32 \\
\hline $\mathrm{O}_{2}(\mathrm{~g})$ & -56.39 & -55.99 & -59.99 & -59.99 & -55.99 & -54.79 \\
\hline Pyrochroite & - & - & - & - & -15.31 & -14.92 \\
\hline Pyrolusite & - & - & - & - & -27.89 & -26.90 \\
\hline Schwertmannite & 0.74 & 0.92 & -1.30 & -1.44 & 1.07 & 1.70 \\
\hline $\mathrm{Zn}(\mathrm{OH})_{2}(\mathrm{e})$ & - & - & - & - & -11.88 & -11.67 \\
\hline
\end{tabular}

primarily to their different sizes with the larger Podwiśniówka water body having a different rate of evaporation.

\subsection{Sulfur Sources and Formation of Dissolved Sulfates}

As mentioned before, the $\delta^{34} \mathrm{~S}$ values of dissolved sulfates of the three ponds examined (mean of $-13.6 \%$ ) are similar to those (mean of $-15.6 \%$ ) derived from the previous geochemical study conducted in the Podwiśniówka acid pit pond (Migaszewski et al. 2008). The ${ }^{34} \mathrm{~S}$-depletion of these $\mathrm{SO}_{4}{ }^{2-}$ ions also reflects the negative $\delta^{34} \mathrm{~S}$ isotope signature of pyrite (mean of $-25.4 \%$ ) and efflorescent sulfate salts (mean of $-25.6 \%$ ) (Migaszewski et al. 2008). The results derived from other studies have shown that the $\delta^{34} \mathrm{~S}$ of dissolved sulfates should be identical to parent sulfide minerals under quantitative disequilibrium oxidation (Taylor and Wheeler 1994). These results suggest that the only potential source of sulfates in the pit pond water is pyrite derived from the exposed pyrite mineralization zone and pyritaceous clayey shales.

The recent atmospheric input of sulfur in the pond waters may be negligible as a significant source of $\mathrm{SO}_{4}{ }^{2-}$ in the Holy Cross Mts, as the measured concentration of $\mathrm{SO}_{4}{ }^{2-}$ in snowpack samples are about $2.5 \mathrm{mg} / \mathrm{L}$ with a $\delta^{34} \mathrm{~S}$ signature close to the range of 5.1-6.8 \%o (Michalik and Migaszewski 2012). This isotopic signature of the snowpack is similar to that $\left(1.2-6.2 \% \delta^{34} \mathrm{~S}\right)$ recorded in rainwater of the neighboring Lublin province (Trembaczowski 1989). Another anthropogenic source, which is often considered in many environmental studies, is fertilizers, manure and sewage. In Europe, they are characterized mostly by positive $\delta^{34} \mathrm{~S}$ and $\delta^{18} \mathrm{O}$ isotope signatures (Table 1 in Szynkiewicz et al. 2011), 
Table 5 Isotope composition of $\mathrm{SO}_{4}{ }^{2-}$ and $\mathrm{H}_{2} \mathrm{O}$ versus $\mathrm{pH}$ values and $\mathrm{SO}_{4}{ }^{2-}$ concentrations of three pond waters

\begin{tabular}{|c|c|c|c|c|c|c|c|}
\hline \multirow[t]{2}{*}{ Location } & \multirow[t]{2}{*}{$\mathrm{pH}$} & \multirow{2}{*}{$\begin{array}{l}\mathrm{SO}_{4}{ }^{2-} \\
(\mathrm{mg} / \mathrm{L})\end{array}$} & \multirow{2}{*}{$\begin{array}{l}\text { Sampling } \\
\text { date }\end{array}$} & \multicolumn{2}{|l|}{$\mathrm{SO}_{4}{ }^{2-}$} & \multicolumn{2}{|l|}{$\mathrm{H}_{2} \mathrm{O}$} \\
\hline & & & & $\begin{array}{l}\delta^{34} \mathrm{~S}_{\mathrm{V}-\mathrm{CDT}} \\
(\% \mathrm{o})\end{array}$ & $\delta^{18} \mathrm{O}_{\mathrm{V}-\mathrm{SMOW}}$ & $\delta^{18} \mathrm{O}_{\mathrm{V}-\mathrm{SMOW}}$ & $\delta \mathrm{D}_{\mathrm{V} \text {-SMOW }}$ \\
\hline Pw acid pit pond & 2.7 & 134 & Jun. 8, 2010 & -11.5 & -4.4 & -6.1 & -51.2 \\
\hline MD acid pond & 2.8 & 731 & & -15.1 & -8.1 & -9.6 & -71.3 \\
\hline MD fish pond & 5.8 & 70 & & -9.5 & -4.3 & -11.1 & -80.7 \\
\hline Pw acid pit pond & 2.8 & 196 & Jul. 16, 2010 & -13.9 & -3.6 & -1.6 & -29.7 \\
\hline MD acid pond & 3.3 & 965 & & -14.0 & -5.8 & -9.8 & -72.4 \\
\hline Pw acid pit pond & 1.8 & 106 & Sept. 30, 2010 & -11.9 & -3.6 & -7.1 & -60.3 \\
\hline MD acid pond & 2.4 & 295 & & -13.9 & -3.2 & -10.5 & -78.3 \\
\hline Pw acid pit pond & 1.8 & 115 & Nov. 12, 2010 & -16.2 & -3.3 & -6.9 & -56.9 \\
\hline MD acid pond & 2.9 & 785 & & -14.6 & -6.0 & -10.6 & -76.2 \\
\hline Pw acid pit pond & 2.8 & 111 & Dec. 15,2010 & -13.8 & -3.7 & -8.9 & -70.2 \\
\hline MD acid pond & 3.6 & 785 & & -14.1 & -5.8 & -10.8 & -77.4 \\
\hline Pw acid pit pond & 3.1 & 108 & Mar. 25, 2011 & -14.2 & -5.0 & -9.2 & -71.3 \\
\hline MD acid pond & 3.5 & 792 & & -15.6 & -6.3 & -10.5 & -75.3 \\
\hline MD fish pond & 6.0 & 108 & & -11.6 & -3.6 & -11.3 & -80.5 \\
\hline
\end{tabular}

for example $\delta^{34} \mathrm{~S}=5 \%$ and $\delta^{18} \mathrm{O}=12 \%$ for fertilizers and $\delta^{34} \mathrm{~S}=9.6 \%$ and $\delta^{18} \mathrm{O}=10 \%$ for sewage (Otero et al. 2008). However, sulfate from these sources are likely negligible because most of the study area is occupied by a mining field, woods and wastelands, with only scarce farmlands.

No matter what the source of sulfur is, there are two potential transformation processes that may influence concentrations and isotope signatures of dissolved sulfate in the three ponds examined:

1. Oxidation of pyrite combined with anaerobic bacterial (dissimilatory) sulfate reduction (BSR);

2. Mineralization of carbon-bonded sulfur compounds (CS-mineralization) in humicmixed soils and debris covers under aerated conditions.

The previous study conducted by Migaszewski et al. (2008) indicated that the pathway of dissolved sulfates from the pyrite-rich zone (mean of $-25.6 \%$ ) to the pit pond would also be mapped out by intermittent red acid puddles that show the intermediate $\delta^{34} \mathrm{~S}-$ $\mathrm{SO}_{4}{ }^{2-}$ values of $-22.3 \%$ ( and $\delta^{18} \mathrm{O}_{-} \mathrm{SO}_{4}{ }^{2-}=-4.4 \%$ ). The distinct shift toward more positive $\delta^{34} \mathrm{~S}_{-} \mathrm{SO}_{4}{ }^{2-}$ values is the evidence for anaerobic bacterial (dissimilatory) sulfate reduction (Fig. 4) that leads to enrichment of residual sulfate in ${ }^{34} \mathrm{~S}$ (e.g., Habicht and Canfield 1997; Mayer et al. 2004; Edraki et al. 2005). This may also be evidenced by the same trend of $\delta^{34} \mathrm{~S}$ or $\delta^{18} \mathrm{O}$ values versus reciprocal $\mathrm{SO}_{4}{ }^{2-}$ concentration plots (Fig. 5). However, a weak correlation coefficient value $\left(r^{2}\right)=\sim 0.40$ may suggest that there is a mixing trend, and thus, the isotopic changes in sulfate are controlled by additional overlapping processes. In contrast to BSR, increasing sulfate concentrations associated with a decrease of $\delta^{34} \mathrm{~S}-\mathrm{SO}_{4}{ }^{2-}$ and $\delta^{18} \mathrm{O}-\mathrm{SO}_{4}{ }^{2-}$ values point to oxidation of sulfide minerals (e.g., Fennell and Bentley 1998; Knöller et al. 2004). Moreover, this excludes mixing of sulfates from pyrite oxidation with sulfates derived from other sources, such as atmospheric deposition or land use (fertilizers, manure or sewage). 

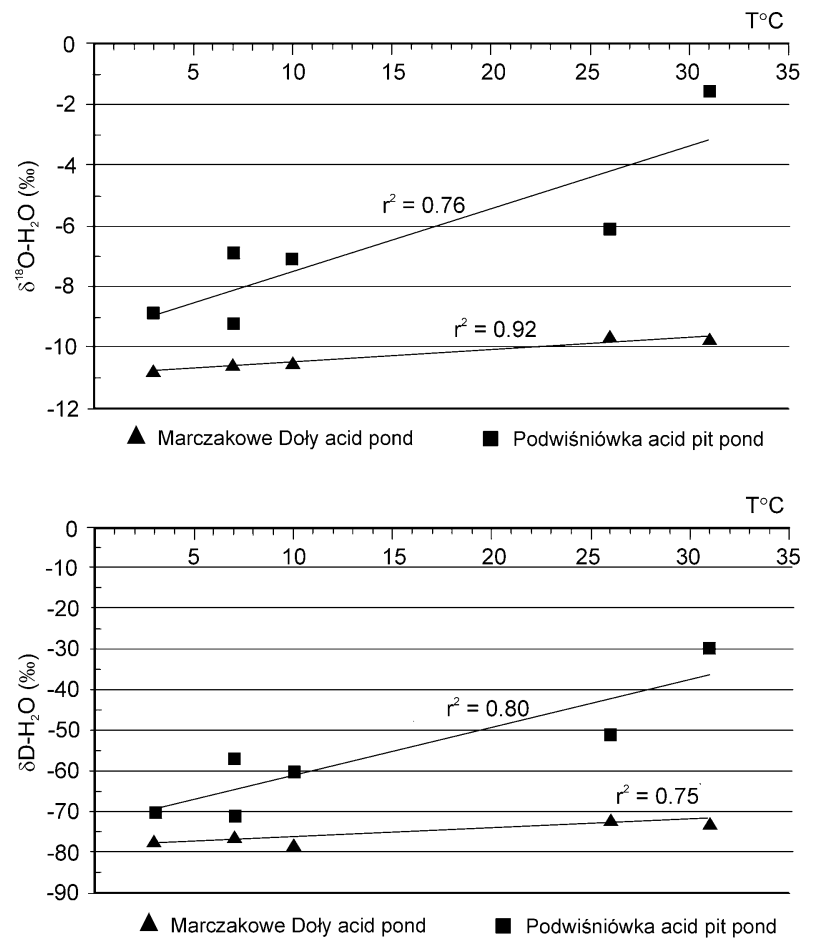

Fig. 3 The $\delta^{18} \mathrm{O}_{\mathrm{V}-\mathrm{Smow}}-\mathrm{H}_{2} \mathrm{O}$ and $\delta \mathrm{D}_{\mathrm{V} \text {-SMOw }}-\mathrm{H}_{2} \mathrm{O}$ values versus temperature $(T)$ of the pond waters

It is difficult to assess sulfur isotope fractionations during precipitation, dissolution and transformation of various secondary minerals. These fractionations are usually small, but maybe they contribute in some way to the observed $\delta^{34} \mathrm{~S}_{-} \mathrm{SO}_{4}{ }^{2-}$ variations during repeating cycles of precipitation, dissolution and transformation of secondary minerals while hydrological conditions change between seasons.

During CS-mineralization, the light isotope ${ }^{32} \mathrm{~S}$ is preferentially metabolized and most of the oxygen atoms are incorporated into $\mathrm{SO}_{4}{ }^{2-}$ from ${ }^{18} \mathrm{O}$-depleted water. This is the reason why typical soil sulfates exhibit $\delta^{18} \mathrm{O}$ values in the range of 0-5 \%o (Mayer et al. 1995). The CS-mineralization can produce an isotopic shift between carbon-bound organic soil sulfur and metabolized $\mathrm{SO}_{4}{ }^{2-}$ up to $5 \%$. Consequently, the remaining $\mathrm{SO}_{4}{ }^{2-}$ becomes progressively enriched in ${ }^{34} \mathrm{~S}$ and ${ }^{18} \mathrm{O}$ as $\mathrm{SO}_{4}{ }^{2-}$ concentration decreases (Mayer et al. 1995). The isotope study conducted in Świętokrzyski National Park (about $15 \mathrm{~km}$ east of the study area) showed that CS-mineralization in soils and debris was a source of positive $\delta^{34} \mathrm{~S}-\mathrm{SO}_{4}{ }^{2-}$ and $\delta^{18} \mathrm{O}-\mathrm{SO}_{4}{ }^{2-}$ values in spring waters, varying from 0.5 to $6.4 \%$ and from 3.5 to $6.4 \%$, respectively (Michalik and Migaszewski 2012). This suggests that this process does not play a major role as a potential source of sulfate in the study area. However, the CS-mineralization may additionally influence concentrations and isotope signatures of dissolved sulfate in the Marczakowe Doły acid and fish ponds, which are constantly recharged from perched aquifers. In contrast, both topography of the Podwiśniówka quarry and exposed mineralization zone favor oxidation of pyrite. In addition, the pathways of dissolved sulfates from the pyrite-rich zone generally lack soil and vegetation. 


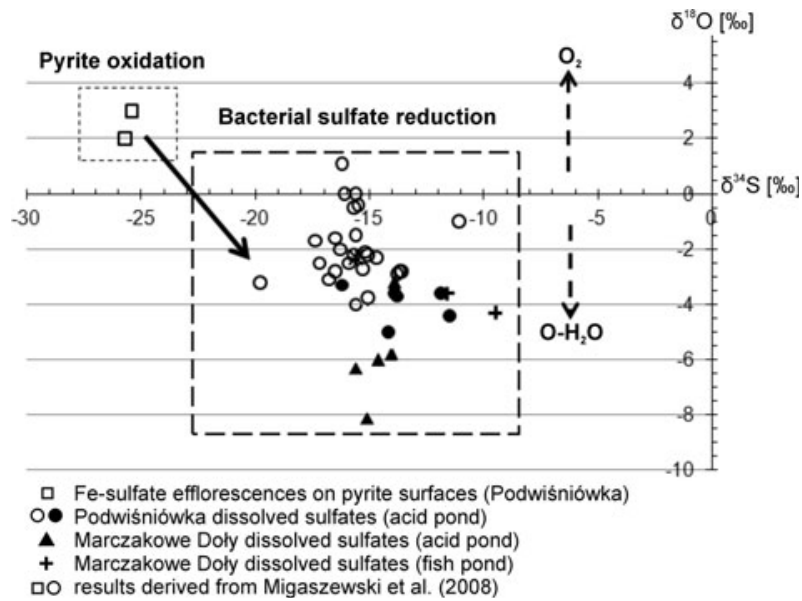

Fig. 4 The $\delta^{34} \mathrm{~S}_{\mathrm{V}-\mathrm{CDT}}-\mathrm{SO}_{4}{ }^{2-}$ versus $\delta^{18} \mathrm{O}_{\mathrm{V}-\mathrm{SMOW}}-\mathrm{SO}_{4}{ }^{2-}$ values of the pond waters with plausible dissolved sulfate end member sources [some of the $\delta^{34} \mathrm{~S}$ and $\delta^{18} \mathrm{O}$ values for the Podwiśniówka acid pit pond are taken from Migaszewski et al. (2008)]
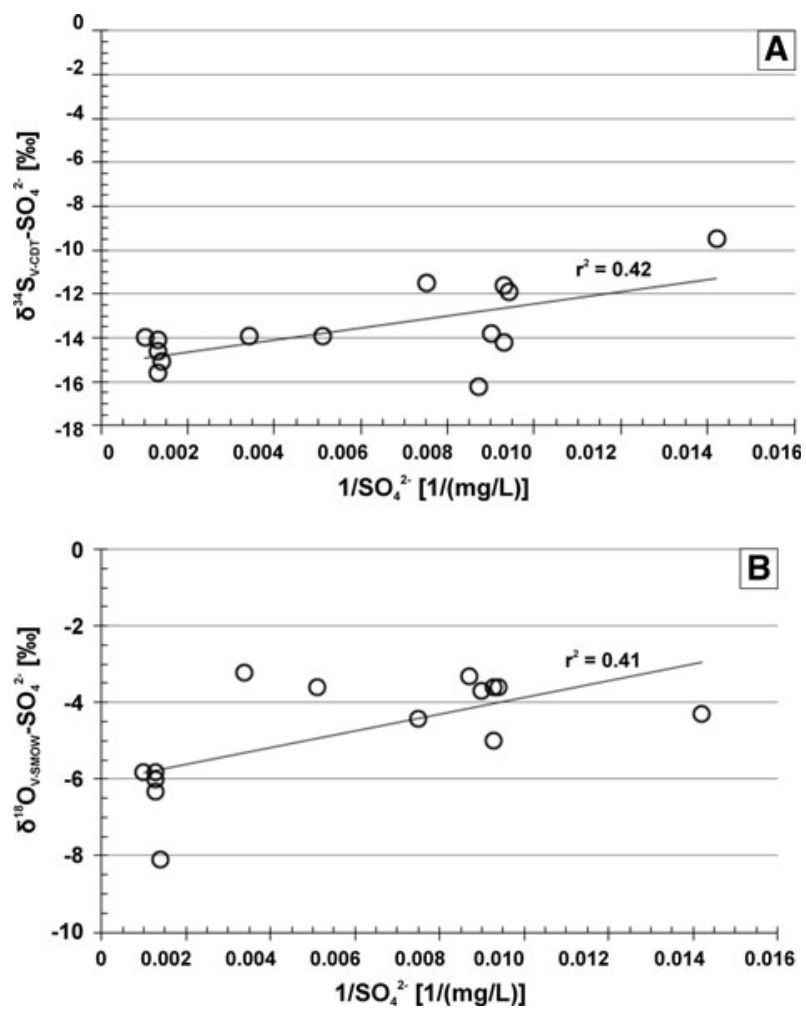

Fig. 5 The $\delta^{34} \mathrm{~S}_{\mathrm{V}-\mathrm{CDT}}-\mathrm{SO}_{4}^{2-}$ and $\delta^{18} \mathrm{O}_{\mathrm{V}-\mathrm{SMOW}}-\mathrm{SO}_{4}^{2-}$ values versus reciprocal sulfate concentrations in the Podwiśniówka pond waters 


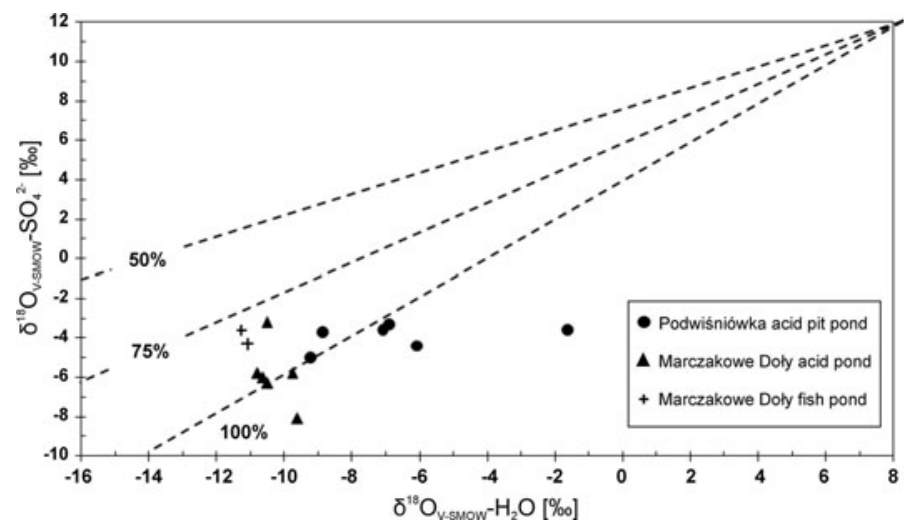

Fig. 6 The $\delta^{18} \mathrm{O}_{\mathrm{V}-\mathrm{SmOw}}-\mathrm{SO}_{4}^{2-}$ versus $\delta^{18} \mathrm{O}_{\mathrm{V}-\mathrm{SmOw}}-\mathrm{H}_{2} \mathrm{O}$ values of pond waters [dashed lines are taken from Butler (2007)]

The similar $\delta^{34} \mathrm{~S}-\mathrm{SO}_{4}{ }^{2-}$ values of three ponds indicate very small sulfur isotope fractionation. Moreover, they also provide evidence for a common source of $\mathrm{SO}_{4}{ }^{2-}$ ions. However, the distribution patterns of $\delta^{34} \mathrm{~S}-\mathrm{SO}_{4}{ }^{2-}$ versus $\delta^{10} \mathrm{O}-\mathrm{SO}_{4}{ }^{2-}$ values in the three ponds examined point to a diverse contribution of pyrite oxidation, BSR and partly CSmineralization. In contrast to the Podwiśniówka acid pit pond and Marczakowe Doły fish pond, the Marczakowe Doły acid pond exhibits the distinct shift toward lower $\delta^{34} \mathrm{~S}_{-} \mathrm{SO}_{4}{ }^{2-}$ values and only minor sulfur isotope fractionation (Fig. 4). This may also indicate a major contribution of sulfates derived from pyrite oxidation.

Another question that should be considered is which pathway of pyrite oxidation induces acidification of pond waters. As mentioned in the Sect.1, there are two pathways, caused by two oxidants: (1) oxygen and (2) ferric iron $\left(\mathrm{Fe}^{3+}\right)$ (reactions 1,4$)$. If pyrite is oxidized in aerobic environment, $87.5 \%$ of oxygen with a $\delta^{18} \mathrm{O}$ signature of $+23.8 \%$ o (Van Everingden and Krouse 1985) in the $\mathrm{SO}_{4}{ }^{2-}$ molecule is incorporated from atmosphere and $12.5 \%$ of oxygen from water (Evangelou and Zhang 1995). In case the pyrite is oxidized by $\mathrm{Fe}^{3+}$ in anoxic environment, $100 \%$ of oxygen comes from water. The relative proportions of oxygen incorporated from air $\left(X_{\text {air }}\right)$ and water $\left(X_{\text {water }}\right)$ may be computed from the Eq. (5) suggested by Taylor et al. (1984):

$$
\begin{aligned}
\delta^{18} \mathrm{O}_{\text {sulfate }}= & X_{\text {water }}\left(\delta^{18} \mathrm{O}_{\text {water }}+\varepsilon_{\text {water }}\right)+\left(1-X_{\text {water }}\right) \\
& \times\left[0.875\left(\delta^{18} \mathrm{O}_{\text {air }}+\varepsilon_{\text {air }}\right)+0.125\left(\delta^{18} \mathrm{O}_{\text {water }}+\varepsilon_{\text {water }}\right)\right]
\end{aligned}
$$

where $\varepsilon_{\text {air }}\left(-11.2 \%\right.$ ) and $\varepsilon_{\text {water }}(+4.1 \%$ ) are enrichment factors (Van Everingden and Krouse 1985), a $\delta^{18} \mathrm{O}_{\text {air }}$ is $+23.8 \%$, whereas the $\delta^{18}$ Owater varied from -11.3 to $-1.6 \%$ o (Table 5). The $\delta^{18} \mathrm{O}-\mathrm{SO}_{4}{ }^{2-}$ versus $\delta^{18} \mathrm{O}-\mathrm{H}_{2} \mathrm{O}$ values of water samples are plotted in Fig. 6. This study shows that $75-100 \%$ of sulfate oxygen is derived from water during formation of dissolved sulfates. However, the Podwiśniówka acid pond is highlighted by more anoxic conditions than the other two ponds, and the contribution of water oxygen is higher, reaching in most cases $100 \%$ (Figs. 4, 6).

\section{Conclusions}

The following conclusions can be drawn from the geochemical and isotopic data derived from this study: 
1. The Podwiśniówka and Marczakowe Doły acid pond waters exhibit different $\mathrm{pH}$ and concentrations of $\mathrm{SO}_{4}{ }^{2-}$ and trace elements. The latter pond reveals a higher $\mathrm{pH}$ and concentrations of As, Fe and Mn. It is also highlighted by different mineralogy of its precipitate with the predominance of schwertmannite and goethite. In contrast, the Podwiśniówka acid pit pond sediment consists of quartz, illite, chlorite and kaolinite with some admixture of jarosite reflecting a more acidic environment. Precipitation of schwertmannite brings about depletion of $\mathrm{Fe}^{3+}$ in the Marczakowe Doły acid pond water.

2. The saturation indices indicated that schwertmannite and nanosized $\varepsilon-\mathrm{Fe}_{2} \mathrm{O}_{3}\left(\mathrm{Fe}^{3+}\right.$ oxide polymorph) were closest to thermodynamic equilibrium state with water, varying from -1.44 to 3.05 and from -3.42 to 6.04 , respectively. It is noteworthy that in the Marczakowe Doły acid pond, schwertmannite and nanosized $\varepsilon-\mathrm{Fe}_{2} \mathrm{O}_{3}$ likely did not precipitate on December 15 of 2010 and March 25 of 2011 due to the lack of $\mathrm{Fe}^{3+}$ ions.

3. The $\delta^{34} \mathrm{~S}$ values of $\mathrm{SO}_{4}{ }^{2-}$ ions from the pond waters examined reflect the mineralogy of the study area. The only sulfide is pyrite that occurs in quartz veins and in a majority of clayey shales. The negative $\delta^{34} \mathrm{~S}$ values of $\mathrm{SO}_{4}{ }^{2-}$ and pyrite indicate that atmospheric or land use sulfur input can be negligible.

4. The $\mathrm{SO}_{4}{ }^{2-}$ ions formed by bacterially induced pyrite oxidation combined with bacterially (dissimilatory) dissolved sulfate reduction and presumably with subordinate mineralization of carbon-bonded sulfur compounds, especially in both Marczakowe Doły ponds. However, the most interesting finding of this study is that the dissolved sulfates likely undergo substantial biogeochemical alteration in the acid pond waters because the $\delta^{34} \mathrm{~S}_{-} \mathrm{SO}_{4}{ }^{2-}$ greatly differed (higher in average by $10 \%$ ) compared to the initial $\delta^{34} \mathrm{~S}$ of pyrite.

5. The $\delta^{34} \mathrm{~S}_{-} \mathrm{SO}_{4}{ }^{2-}$ and $\delta^{18} \mathrm{O}-\mathrm{H}_{2} \mathrm{O}$ data provide evidence for prevailing pyrite oxidation with ferric iron (reaction 4) and subordinate atmospheric oxygen (reaction 1).

6. The Podwiśniówka acid pit pond exhibited distinct seasonal variations in both $\delta^{18} \mathrm{O}-$ $\mathrm{H}_{2} \mathrm{O}(-9.2$ to -1.6$)$ and $\delta \mathrm{D}-\mathrm{H}_{2} \mathrm{O}(-29.7$ to -71.3$)$ values. The high correlation coefficient $\left(r^{2}=0.99\right)$ between $\delta^{18} \mathrm{O}-\mathrm{H}_{2} \mathrm{O}$ and $\delta \mathrm{D}-\mathrm{H}_{2} \mathrm{O}$ values indicates atmospheric precipitation as the only source of water.

7. The results of the isotope and trace metal determinations indicate that there is no hydraulic connection between the three pond examined.

The complex geology and unique water geochemistry of three ponds in the Podwiśniówka area give an opportunity for a direct insight into the complex mineral-rock-water interactions.

Acknowledgments We wish to express special thanks to Professor Zbigniew Sawłowicz of the Institute of Geological Sciences, Jagiellonian University in Cracow, and Łukasz Kruszewski and Michał Kuźniarski of the Institute of Geological Sciences of the Polish Academy of Sciences in Warsaw for SEM and XRD determinations and valuable remarks. Thanks are due to Dr. Stanisław Chmiel, UMCS, Faculty of Geosciences, for access to the PICARRO Analyzer.

Open Access This article is distributed under the terms of the Creative Commons Attribution License which permits any use, distribution, and reproduction in any medium, provided the original author(s) and the source are credited. 


\section{References}

Acero P, Ayora C, Torrentó C, Nieto J-M (2006) The behavior of trace elements during schwertmannite precipitation and subsequent transformation into goethite and jarosite. Geochim Cosmochim Acta 70:4130-4139

Banks D, Younger PL, Arnesen R-T, Iversen ER, Banks SB (1997) Mine-water chemistry: the good the bad and the ugly. Environ Geol 32(3):157-174

Bednar AJ, Garbarino JR, Ranville JF, Wildeman TR (2005) Effects of iron on arsenic speciation and redox chemistry in acid mine water. J Geochem Explor 85:55-62

Bigham JM, Schwertmann U, Carlson L, Murad E (1990) A poorly crystallized oxyhydroxysulfate of iron formed by bacterial oxidation of Fe(II) in acid mine waters. Geoch Cosmochim Acta 54:2743-2758

Bigham JM, Carlson L, Murad E (1994) Schwertmannite, a new iron oxyhydroxysulphate from Pyhasalmi, Finland, and other localities. Miner Magaz 58(393):641-648

Bigham JM, Schwertmann U, Traina SJ, Winland RL, Wolf M (1996) Schwertmannite and the chemical modeling of iron in acid sulfate waters. Geochim Cosmochim Acta 60:2111-2121

Bourrié G, Trolard F, Génin J-MR, Jaffrezic A, Maître V, Abdelmoula M (1999) Iron control by equilibria between hydroxy-green rusts and solutions in hydromorphic soils. Geochim Cosmochimi Acta 63:3417-3427

Butler TW (2007) Isotope geochemistry of drainage from an acid mine impaired watershed, Oakland, California. App Geochem 22:1416-1426

Cánovas CR, Hubbard CG, Olías M, Nieto JM, Black S, Coleman ML (2008) Hydrochemical variations and contaminant load in the Rio Tinto (Spain) during flood events. J Hydrol 350:25-40

Choudhry M, Aggarwal P, van Duren M, Poltenstein L, Araguas L, Kurttas T (2011) Fourth interlaboratory comparison exercise for $\delta^{2} \mathrm{H}$ and $\delta^{18} \mathrm{O}$ analysis of water samples (WICO2011), Isotope Hydrology Laboratory, IAEA, Vienna, December 2011. http://www-naweb.iaea.org/napc/ih/documents/other/ReportWICO2011-draft.pdf

Cidu R, Biddau R, Fanfani L (2009) Impact of past mining activity on the quality of groundwater in SW Sardinia (Italy). J Geochem Explo 100:125-132

Cravotta CA III (2008a) Dissolved metals and associated constituents in abandoned coal-mine discharges, Pennsylvania, USA: 1. Constituent concentrations and correlations. Appl Geochem 23:166-202

Cravotta CA III (2008b) Dissolved metals and associated constituents in abandoned coal-mine discharges, Pennsylvania, USA: 2. Geochemical controls on constituent concentrations. Appl Geochem 23:203-226

Druschel GK, Baker BJ, Gihring TM, Banfield JF (2004) Acid mine drainage biogeochemistry at Iron Mountain, California. Geochem Trans 5(2):13-32

Edraki M, Golding SD, Baublys KA, Lawrence MG (2005) Hydrochemistry, mineralogy and sulfur isotope geochemistry of acid mine drainage at the Mt. Morgan mine environment, Queensland, Australia. Appl Geochem 20:789-905

Evangelou VP, Zhang YL (1995) A review: pyrite oxidation mechanism and acid mine drainage prevention. Environ Sci Technol 25:141-199

Fennell J, Bentley LR (1998) Distribution of sulfate and organic carbon in a prairie till setting: natural versus industrial sources. Water Resour Res 34:1781-1794

Habicht KS, Canfield DE (1997) Sulfur isotope fractionation during bacterial sulfur reduction in organicrich sediments. Geochim Cosmochim Acta 61:5351-5361

Hałas S, Szaran J (2004) Use of $\mathrm{Cu}_{2} \mathrm{O}-\mathrm{NaPO}_{3}$ mixtures for $\mathrm{SO}_{2}$ extraction from $\mathrm{BaSO}_{4}$ for sulfur isotope analysis. Isot Environ Health Stud 40(3):229-231

Hałas S, Szaran J, Czarnacki M, Tanweer A (2007) Refinements in $\mathrm{BaSO}_{4}$ to $\mathrm{CO}_{2}$ preparation and $\delta^{18} \mathrm{O}$ calibration of the sulfate reference materials NBS-127, IAEA SO-5 and IAEA SO-6. Geostand Geoanal Res 31(1):61-68

Hazen JM, Williams MW, Stover B, Wireman M (2002) Characterization of acid mine drainage using a combination of hydrometric, chemical and isotopic analyses, Mary Murphy Mine, Colorado. Environ Geochem Health 24:1-22

Hoefs J (2009) Stable isotope geochemistry, 6th edn. Springer, Berlin

Ingraham NL (1998) Isotopic variations in precipitation. In: Kendall C, McDonnell JJ (eds) Isotope tracers in catchment hydrology. Elsevier, Amsterdam, pp 87-118

Knöller K, Fauville A, Mayer B, Strauch G, Friese K, Veizer J (2004) Sulfur cycling in an acid mining lake and its vicinity in Lusatia, Germany. Chem Geol 204:303-323

Kusakabe M (2005) A closed pentane trap for separation of $\mathrm{SO}_{2}$ from $\mathrm{CO}_{2}$ for precise $\delta^{18} \mathrm{O}$ and $\delta^{34} \mathrm{~S}$ measurements. Geochem J 39:285-287 
Majzlan J, Navrotsky A, Schwertmann U (2004) Thermodynamics of iron oxides: Part III. Enthalpies of formation and stability of ferrihydrite $\left(\mathrm{Fe}(\mathrm{OH})_{3}\right)$, schwertmannite $\left(\mathrm{FeO}(\mathrm{OH})_{3 / 4}\left(\mathrm{SO}_{4}\right)_{1 / 8}\right)$ and e- $\mathrm{Fe}_{2} \mathrm{O}_{3}$. Geochim Cosmochim Acta 68:1049-1059

Mayer B (2006) The use of stable isotopes to trace nutrients and pollutants in aquatic systems. 2006 Intern Symp on Our Future Resour, Groundwater. Korea Institute of Geoscience and Mineral Resources, Jeju Island, South Korea, May 24-26, 2006. Proceedings Volume, pp 103-118

Mayer B, Fritz P, Prietzel J, Krouse HR (1995) The use of stable sulfur and oxygen isotope ratios for interpreting the mobility of sulfate in aerobic forest soils. Appl Geochem 10:161-173

Mayer B, Prietzel J, Krouse HR (2004) The influence of sulfur deposition rates on sulfate retention patterns and mechanisms in aerated forest soils. Appl Geochem 16:1003-1019

Mayo AL, Nielsen PJ, Loucks M, Brimhall WH (1992) The use of solute and isotope chemistry to identify flow patterns and factors which limit acid mine drainage in the Wasatch Range, Utah. Ground Water 30(20):243-249

Michalik A, Migaszewski ZM (2012) Stable sulfur and oxygen isotope ratios of the Świętokrzyski National Park spring waters generated by natural and anthropogenic factors (south-central Poland). Appl Geochem 27:1123-1132

Migaszewski ZM, Gałuszka A, Pasławski P, Starnawska E (2007) An influence of pyrite oxidation on generation of unique acid pit water: a case study, Podwiśniówka quarry, Holy Cross Mountains (southcentral Poland). Pol J Environ Stud 16(3):407-442

Migaszewski ZM, Gałuszka A, Hałas S, Dołęgowska S, Dąbek J, Starnawska E (2008) Geochemistry and stable sulfur and oxygen isotope ratios of the Podwiśniówka pit pond water generated by acid mine drainage (Holy Cross Mountains, south-central Poland). Appl Geochem 23:3620-3634

Mighanetara K, Braungardt CB, Rieuwerts JS, Azizi F (2009) Contaminant fluxes from point and diffuse sources from abandoned mines in the River Tamar catchment, UK. J Geochem Explor 100:116-124

Mizutani Y (1971) An improvement in the carbon-reduction method for the oxygen isotopic analysis of sulphates. Geochem J 5:69-71

Mizutani Y, Oana S (1973) Separation of $\mathrm{CO}_{2}$ from $\mathrm{SO}_{2}$ with frozen n-pentane as a technique for precision analysis of ${ }^{18} \mathrm{O}$ in sulfates. Mass Spectrom 21(3):255-258

Nordstrom DK (2009) Acid rock drainage and climate change. J Geochem Explor 100:97-104

Nordstrom DK (2011a) Hydrogeochemical processes governing the origin, transport and fate of major and trace elements from mine wastes and mineralized rock to surface waters. Appl Geochem 26:1777-1791

Nordstrom DK (2011b) Mine waters: acidic to circumneutral. Elements 7(6):393-398

Nordstrom DK, Southam G (1997) Geomicrobiology of sulfide mineral oxidation. In: Banfield JF, Nealson $\mathrm{KH}$ (eds) Geomicrobiology_interactions between microbes and minerals: reviews in mineralogy, vol 35. Mineralogical Society of America, Washington, DC, pp 361-390

Otero N, Soler A, Canals À (2008) Controls of $\delta 34 \mathrm{~S}$ and $\delta 18 \mathrm{O}$ in dissolved sulphate: learning from a detailed survey in the Llobregat River (Spain). Appl Geochem 23:1166-1185

Parkhurst DL, Apello CAJ (1999) User's guide to PHREEQC (version 2)-a computer program for speciation, batch-reaction, one-dimensional transport, and inverse geochemical calculations. US Geol Surv, Water-Resour Invest Rep, 99-4259

Plumlee GS, Smith KS, Montour MR, Ficklin WH, Mosier EL (1999) Geologic controls on the composition of natural waters and mine waters draining diverse mineral-deposit types. In: Filipek LH, Plumlee GS (eds) The environmental geochemistry of mineral deposits. Part B: case studies and research topics. Society of Economic Geologists, Littleton, pp 373-432

Regenspurg S, Brand A, Peiffer S (2004) Formation and stability of schwertmannite in acidic mining lakes. Geochim Cosmochim Acta 68:1185-1197

Runkel RL, Kimball BA, Walton-Day K, Verplanck PL (2007) A simulation-based approach for estimating premining water quality: Red Mountain Creek, Colorado. Appl Geochem 22:1899-1918

Schwertmann U, Bigham JM, Murad E (1995) The first occurrence of schwertmannite in a natural stream environment. Eur J Mineral 7:547-552

Smedley PL, Kinniburgh DG (2002) A review of the source, behaviour and distribution of arsenic in natural waters. Appl Geochem 17:517-568

Szynkiewicz A, Witcher J, Modelska M, Borrok DB, Pratt LM (2011) Anthropogenic sulfate loads in the Rio Grande, New Mexico. Chem Geol 283:194-209

Taylor BE, Wheeler MC (1994) Sulfur- and oxygen isotope geochemistry of acid mine drainage in the Western United States. In: Alpers CN, Blowes DW (eds) Environmental geochemistry of sulfide oxidation, Am Chem Soc Symp, vol 550. Am Chem Soc Ser, Washington, DC, pp 481-514

Taylor BE, Wheeler MC, Nordstrom DK (1984) Isotope composition of sulfate in acid mine drainage as measure of bacterial oxidation. Nature 308:538-541 
Trembaczowski A (1989) The study of sulfur and oxygen isotope composition in sulfates of groundwaters. Ph.D. Dissertation. Maria Curie-Skłodowska University in Lublin (in Polish)

Van Everingden RO, Krouse HR (1985) Isotope composition of sulphates generated by bacterial and abiological oxidation. Nature 315:395-396

Wadham JL, Bottrell S, Tranter M, Raiswell R (2004) Stable isotope evidence for microbial sulphate reduction at the bed of a polythermal high Arctic glacier. Earth Planet Sci Lett 219:341-345

Żylińska A, Szczepanik Z, Salwa S (2006) Cambrian of the Holy Cross Mountains, Poland: biostratigraphy of the Wiśniówka Hill succession. Acta Geol Pol 56(4):443-461 